\section{PENERAPAN MODEL COOPERATIVE TIPE TGT BERBASIS "ATONG"}

Buku Penerapan Model Cooperative Tipe TGT Berbasis ATONG merupakan buku yang dirancang untuk guru dan calon guru sebagai refrensi pemilihan model pembelajaran dalam menerapkan proses pembelajaran yang inovatif. Model Cooperative tipe TGT Berbasis ATONG merupakan model pembelajaran yang melibatkan kerjasama tim untuk melakukan games akademik yang dilakukan dalam proses pembelajaran, dan proses pembelajaran dipolakan pada suasana A (Amati) terhadap semua situasi belajar, lalu T (Tanya) pada setiap masalah yang muncul, supaya mereka melakukan 0 (Olah) atas jawaban dari pertanyaan, kemudian N (Nalar) untuk berpikiri dari semua jawaban permasalahan yang ada, sampai pada G (Gagas) suatu ide atau inovasi baru. Dengan adanya model pembelajaran Cooperative tipe TGT berbasis ATONG harapanya dapat membantu guru dan calon guru untuk meningkatkan mutu dalam merancang pembelajaran yang inovatif sehingga menghasilkan proses pembelajaran yang efektif, menyenangkan bagi siswa serta membangkitkan aktivitas dan prestasibelajar siswa.

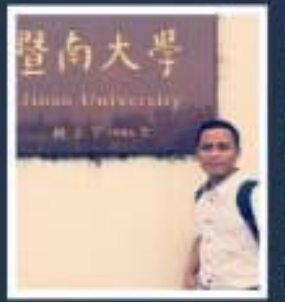

Aji Heru Muslim, M.Pd, Lahir di Banjarnegara, 06 Mei 1989. Riwayat Pendidikan SD-SLTP-SMK ditamatkan di Kabupaten Banjarnegara. Pendidikan S1 di tempuh di Universitas Muhammadiyah Purwokerto (UMP) jurusan PGSD. Pendidikan 52 ditempuh di Universitas Negeri Semarang (UNNES) dengan jurusan Pendidikan Dasar Konsentrasi PGSD. Saat ini sedang menyelesaikan studi lanjut S3 di Universitas Negeri Yogyakarta (UNY) mengambil jurusan Pendidikan Dasar. Penulis saat ini mengabdikan diri sebagai Dosen PGSD di Universitas Muhammadiyah Purwokerto. Pengalaman menjabat struktural diantara lain sebagai kepala Laboratorium Kelas Model PGSD tahun 2012-2013, Koordinator BIPA UMP tahun 2014-2016, Sekertaris Prodi PGSD UMP masa jabatan 2016-2018, dan Sekertaris Program Pendidikan Profesi Guru (PPG) masa jabatan 2018-2020. Selain aktif di akademik kampus penulis ikut aktif dalam organisasi lainya meliputi Pengurus ISPI Kab. Banyumas masa bakti 2014-2019, Pengurus APPBIPA Jawa Tengah masa bakti 2019-2023, Pengurus Daerah ISPI Jawa Tengah masa bakti 2016-2021, dan Pengurus Asosiasi PGSD LPTK PTM masa bakti 2018-2022. Beberapa karya ilmiah diterbitkan berupa buku diantaranya Buku Startegi Belajar Mengajar di Sekolah Dasar, Buku Pendidikan Anak Berkebutuhan Khusus, dan Media Pembelajaran PKn diSD.
PENERAPAN

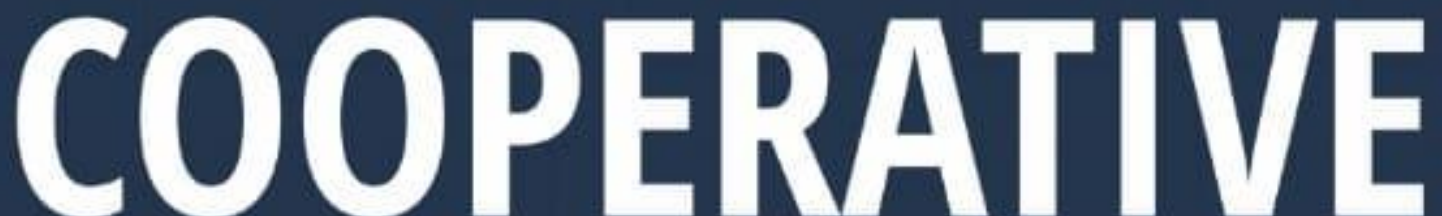
TIPE TGT BERBASIS "ATONG"

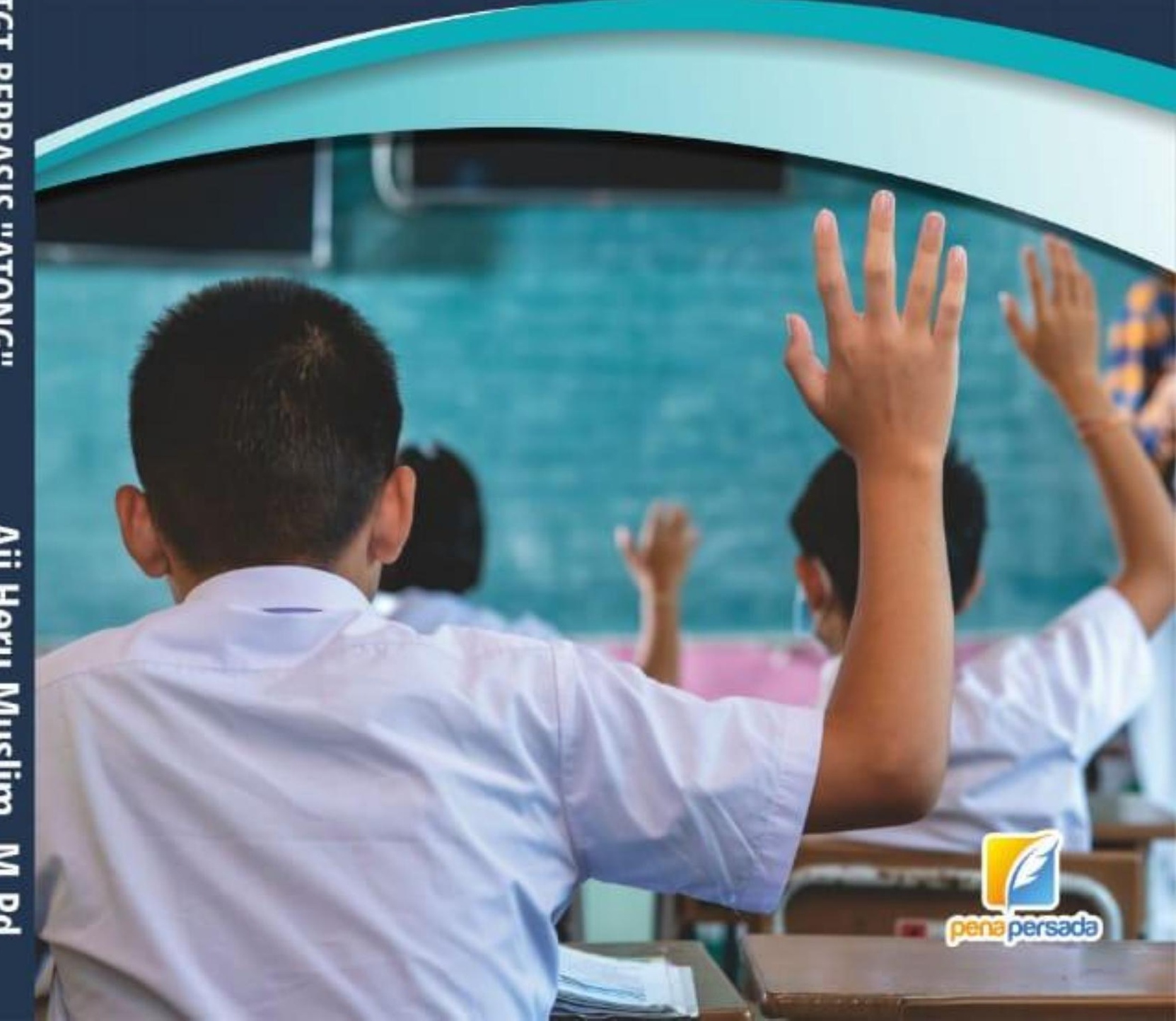




\section{PENERAPAN MODEL COOPERATIVE TIPE TGT BERBASIS "ATONG"}

Aji Heru Muslim, M.Pd.

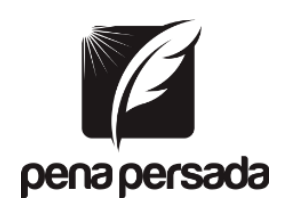

PENERBIT CV. PENA PERSADA 


\title{
PENERAPAN MODEL COOPERATIVE \\ TIPE TGT BERBASIS “ATONG”
}

\author{
Penulis:
}

Aji Heru Muslim, M.Pd.

\section{Editor:}

Wiwit Kurniawan

ISBN : 978-623-6837-25-3

\section{Design Cover :}

Retnani Nur Briliant

\section{Layout :}

Fajar T. Septiono

\section{Penerbit CV. Pena Persada \\ Redaksi :}

Jl. Gerilya No. 292 Purwokerto Selatan, Kab. Banyumas

Jawa Tengah

Email : penerbit.penapersada@gmail.com

Website : penapersada.com Phone : (0281) 7771388

\section{Anggota IKAPI}

All right reserved

Cetakan pertama : November 2020

Hak Cipta dilindungi oleh undang-undang. Dilarang memperbanyak karya tulis ini dalam bentuk apapun tanpa izin penerbit 


\section{KATA PENGANTAR}

Puji syukur kehadirat Allah SWT yang telah melimpahkan rahmat-Nya sehingga buku yang berjudul "Penerapan Model Cooperative Tipe TGT berbasis ATONG" dapat diselesaikan dengan baik. Atas bantuan dari berbagai pihak yang telah berkenan memberikan segala yang dibutuhkan dalam penyusunan buku ini.

Belajar IPS khususnya materi mendeskripsikan perjuangan para tokoh pejuang pada masa penjajahan Belanda dan Jepang dirasa masih sulit bagi siswa. Buku ini merupakan penjabaran atas prosedur pengembangan perangkat pembelajaran serta implementasinya dengan model Cooperative tipe TGT (Team Games Tournament) berbasis ATONG (Amati, Tanya, Olah, Nalar, Gagas). Tujuan buku ini adalah mendeskripsikan prosedur pengembangan perangkat pembelajaran dengan karakteristik model cooperative tipe TGT berbasis ATONG dan perangkat pembelajaran yang valid, praktis dan efektif pada ujicoba.

Prosedur pengembangan yang digunakan adalah model pengembangan 4-D Thiagarajan yang terdiri dari tahap Define, Design, Develop, dan Disseminate. Dalam penelitian ini hanya sampai tahap develop. Jenis perangkat yang dikembangkan adalah: (1) Silabus; (2) RPP; (3) LKS; dan (4) Media Pembelajaran. Perangkat tersebut divalidasi oleh lima orang yang berkompeten dibidangnya. Uji kepraktisan dilakukan dengan subjek peserat didik kelas V SD Negeri 1 Kendaga, uji keefektifan dengan subjek uji adalah peserta didik kelas V SD Negeri 1 Banjarmangu dan SD Negeri 2 Kendaga. Kelas V SD Negeri 1 Banjarmangu sebagai kelas eksperimen dan Kelas V SD Negeri 2 Kendaga sebagai kelas kontrol.

Penulis merasa bahwa buku ini masih jauh dari sempurna. Oleh karena itu, saran dari pembaca yang budiman sangat penulis harapkan. Akhir kata penulis berharap semoga buku ini bermanfaat bagi semua pihak yang membacanya. 


\section{Daftar Isi}

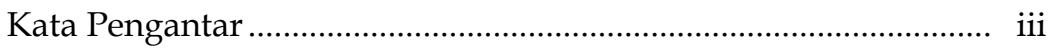

Daftar Isi...................................................................................... iv

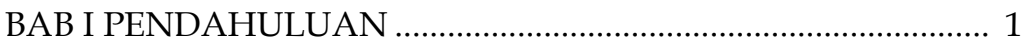

A. Latar Belakang Masalah......................................................... 1

B. Penegasan Istilah ............................................................... 5

BAB II

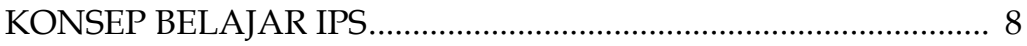

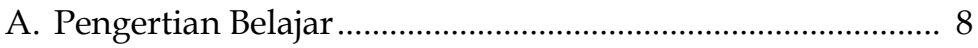

B. Model Cooperatif Learning (CL) ………………................ 9

C. Tipe Team Games Tournament (TGT) .................................... 14

D. Strategi Pembelajaran ATONG.............................................. 17

E. Model Cooperatif tipe TGT berbasis ATONG ....................... 19

F. Pengertian IPS (Ilmu Pengetahuan Sosial) ........................... 22

G. Aktivitas Pembelajaran ....................................................... 23

1. Pengertian Aktivitas Belajar ............................................. 23

2. Prinsip - Prinsip Aktivitas............................................... 24

3. Jenis-Jenis Aktivitas Belajar ................................................ 26

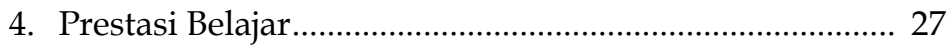

BAB III

PENGEMBANGAN PERANGKAT PEMBELAJARAN ................. 29

A. Prosedur Pengembangan Perangkat Pembelajaran............. 29

B. Tahap Pendefinisian (Define) ……………........................ 31

1. Analisis Awal Akhir ..................................................... 31

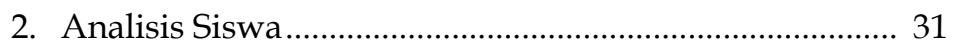

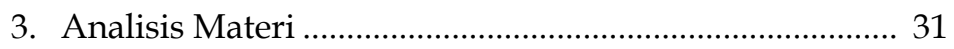

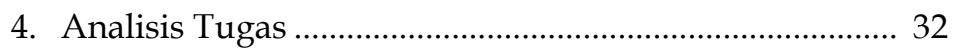

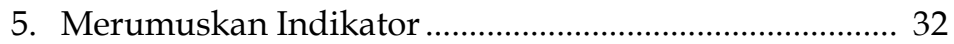

C. Tahap Perancangan (Design) …………………................... 32

1. Penyusunan Tes ............................................................ 32

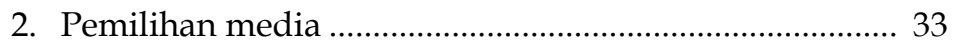

3. Pemilihan format ............................................................ 33 


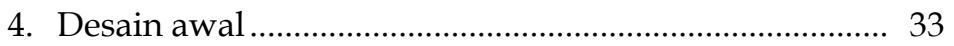

D. Tahap Pengembangan (Develop) …………........................ 34

1. Validasi Perangkat ........................................................ 34

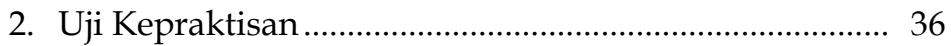

3. Uji coba perangkat (Efektif) ........................................... 39

E. Tahap Pendesiminasian (Disseminate) ................................. 41

F. Kriteria Kevalidan, Keefektifan dan Kepraktisan ................ 46

\section{BAB IV}

KARAKTERISTIK PERANGKAT PEMBELAJARAN YANG DIKEMBANGKAN DAN PENGUJIANNYA

A. Karakteristik perangkat pembelajaran IPS Model Cooperative Tipe TGT berbasis ATONG …………….......... 53

B. Hasil Validasi .................................................................. 59

1. Hasil Validasi Perangkat .............................................. 59

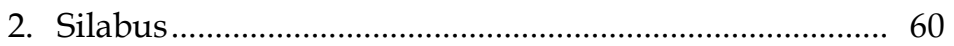

3. Rencana Pelaksanaan Pembelajaran (RPP) ..................... 61

4. Lembar Kerja Siswa (LKS) .............................................. 62

5. Media Pembelajaran ...................................................... 62

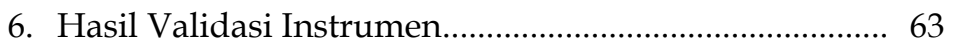

C. Hasil Uji Kepraktisan ........................................................ 65

1. Kemampuan Aktivitas Guru Mengelola Pembelajaran 65

2. Respon Peserta Didik....................................................... 66

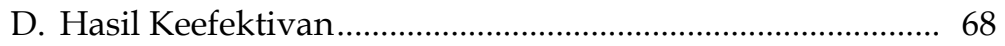

1. Hasil Uji Normalitas dan Homogenitas .......................... 68

2. Hasil uji ketuntasan ....................................................... 71

E. Hasil uji pengaruh Aktivitas peserta didik terhadap prestasi belajar..................................................................... 72

F. Uji Banding Prestasi Belajar Pesarta Didik Kelas Eksperimen dengan Kelas Kontrol ....................................... 75

\section{BAB V}

HASIL PENGEMBANGAN PERANGKAT PEMBELAJARAN ... 77

A. Validasi Perangkat ............................................................ 77

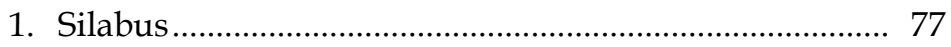

2. Rencana Pelaksanaan Pembelajaran............................... 78 


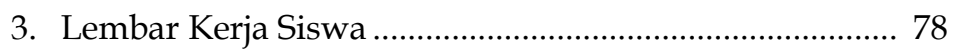

4. Media Pembelajaran ........................................................... 78

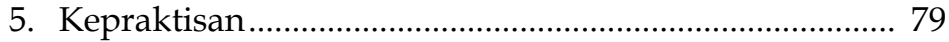

6. Kemampuan Aktivitas Guru Mengelola Pembelajaran. 79

7. Respon Peserta Didik dan Guru ..................................... 79

B. Pembahasan Hasil Uji Coba Perangkat (Efektifitas) ............. 80

1. Prestasi Belajar Mencapai Kriteria Ketuntasan

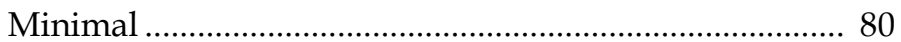

2. Pengaruh Aktivitas Terhadap Prestasi Belajar ................ 81

3. Prestasi Belajar Kelas Eksperimen Dibandingkan Kelas Kontrol

BAB VI

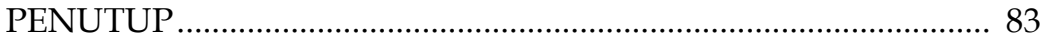

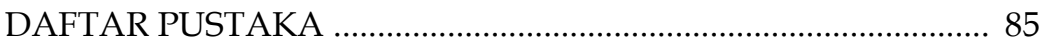




\section{BAB I}

\section{PENDAHULUAN}

\section{A. Latar Belakang Masalah}

Sekolah Dasar sebagai tahap pertama pendidikan, seyogyanya dapat memberikan landasan yang kuat untuk tingkat selanjutnya. Dengan demikian sekolah dasar harus memberikan bekal kemampuan dan keterampilan dasar strategis sejak kelas-kelas awal. Upaya peningkatan mutu pendidikan dasar ini tidak dapat ditunda-tunda lagi terutama dalam peningkatan mutu proses pembelajaran di sekolah dasar era globalisasi.

Hal ini sesuai dengan fungsi pendidikan dasar yang tidak lagi semata-mata berfungsi sebagai sarana sosialisasi siswa. Siswa sejak dini harus dapat menumbuhkan secara potensial manusia Indonesia yang kelak mampu menjadi agen pembaharuan. Pembelajaran di Sekolah Dasar diharapkan dapat menciptakan siswa yang memiliki pengetahuan, pemahaman, keterampilan, serta sikap dan nilai luhur yang harus diamalkan dalam kehidupan sehari-hari baik di lingkungan keluarga maupun masyarakat.

Pasal 3 Undang-Undang No. 20 tahun 2003 tentang Sistem Pendidikan Nasional, menyatakan bahwa pendidikan Nasional berfungsi mengembangkan kemampuan, membentuk watak dan karakter serta peradaban bangsa yang bermartabat dalam rangka mencerdaskan kehidupan bangsa. Hal ini bertujuan untuk berkembangnya potensi peserta didik agar menjadi manusia yang beriman dan bertaqwa kepada Tuhan Yang Maha Esa, berakhlak mulia, sehat, berilmu, cakap, kreatif, mandiri dan menjadi warga negara yang demokratis serta bertanggung jawab. Berdasarkan pasal tersebut, seorang guru dituntut untuk mengembangkan potensi yang dimiliki oleh setiap siswanya dan meningkatkan keterampilan yang harus diamalkan dalam 
kehidupannya, serta menjadikan setiap siswanya untuk menjadi warga negara yang baik dan dapat memajukan negara Indonesia di masa yang akan datang.

Salah satu pembelajaran yang ada di sekolah adalah pembelajaran Ilmu Pengetahuan Sosial (IPS) yang merupakan mata pelajaran yang diberikan di tingkat SD/MI/SDLB. Ilmu Pengetahuan Sosial (IPS) mengkaji seperangkat peristiwa, fakta, konsep, dan generalisasi yang berkaitan dengan isu sosial. Pada jenjang SD/MI, mata pelajaran Ilmu Pengetahuan Sosial (IPS) memuat materi geografis, sejarah, dan ekonomi. Melalui mata pelajaran Ilmu Pengetahuan Sosial (IPS), peserta didik diarahkan untuk dapat menjadi warga masyarakat yang menghargai nilainilai sosial, bertanggung jawab, mencintai lingkungan alam, dan menjadi warga dunia yang cinta damai.

Pembelajaran IPS telah dilaksanakan berbagai pendekatan, namun pembelajarannya masih berlangsung secara tradisional yaitu guru cenderung aktif dalam kelas sedangkan siswa hanya sebagai penerima pasif semua informasi yang disampaikan oleh guru. Hal ini menyebabkan siswa kurang aktif sehingga hasil belajar IPS masih rendah.

Pembelajaran IPS yang selama ini berlangsung, selalu menggunakan metode ceramah dimana guru cenderung lebih aktif, dan siswa hanya berperan pasif dalam pembelajaran. Hal ini menyebabkan pemahaman siswa terhadap materi pembelajaran bersifat abstrak, tidak mendalam dan hanya bersifat sementara, motivasi belajar siswa untuk mempelajari IPS menjadi rendah, dikarenakan pembelajaran tidak menarik, disamping itu siswa di dalam kelas kelihatan pasif dimana siswa hanya duduk diam dan mendengarkan penjelasan guru.

Berdasarkan hasil wawancara dan observasi mengenai perangkat pembelajaran yang digunakan oleh guru dalam proses pembelajaran, dijelaskan bahwa perangkat yang digunakan oleh guru hanya copy paste contoh perangkat pembelajaran yang sudah disiapkan oleh dinas pendidikan terkait. Hal ini dikarenakan kemampuan guru masih kurang dalam mendesain atau merancang perangkat pembelajaran. 
Sebagai contoh kegagalan dalam pembelajaran IPS lainya dalam materi dapat mendeskripsikan perjuangan para tokoh pejuang pada masa penjajahan Belanda dan Jepang adalah siswa SD yang tidak dapat mendeskripsikan perjuangan para tokoh pejuang pada masa penjajahan Belanda dan Jepang. Dari wawancara dengan beberapa siswa ditemukan bahwa mereka kurang mengetahui perjuangan para tokoh pada masa penjajahan Belanda dan Jepang karena banyak materi yang harus dihafalkan dan dipahami. Jika hal ini dibiarkan berlarutlarut, maka para siswa akan mengalami kesulitan dalam mengidentifikasi perjuangan para tokoh pejuang pada masa penjajahan Belanda dan Jepang.

Model pembelajaran Cooperatif tipe Team Games Tournament (TGT) adalah sebagai suatu kegiatan kompetisi yang dimaksudkan untuk merangsang siswa untuk bekerja sama dengan kelompoknya (Slavin, 2008: 167). Pembelajaran ini merupakan salah satu kegiatan pembelajaran yang banyak melibatkan siswa dalam proses memahami suatu materi pelajaran dengan tidak memberikan rasa kejenuhan pada siswa dalam proses belajar di sekolah, dan dalam Team Games Tournament (TGT) ini siswa dapat lebih aktif dalam mengikuti kegiatan, mampu melakukan kerja sama dengan kelompoknya dan siswa dapat dengan bebas memahami suatu materi pelajaran dengan menyenangkan juga dapat berpengaruh terhadap nilai prestasi belajar siswa.

Oleh karena itu salah satu inovasi yang menarik mengiringi perkembangan pembelajar di sekolah dasar perlu dikembangkan perangkat pembelajaran IPS yang dapat meningkatkan aktivitas dan hasil belajar siswa. Salah satu alternatif model pembelajaran adalah model cooperative learning tipe Team Games Tournament (TGT) berbasis ATONG, dimana siswa selalu dipolakan untuk $\mathrm{A}$ (=amati) terhadap semua situasi belajar, $\mathrm{T}(=$ tanya) pada setiap masalah muncul, lalu $\mathrm{O}(=$ olah $)$ atas jawaban dari pertanyaan, kemudian $\mathrm{N}(=$ nalar) untuk diteruskan sampai pada $\mathrm{G}$ (=gagas) suatu ide atau inovasi baru. 
Team Games Tournament (TGT) pada mulanya dikembangkan oleh David De Vries dan Keith Edwards (Slavin, 2008:13). Metode ini menggunakan pelajaran yang disampaikan guru kepada tim kerja/kelompok dan pada akhir pokok bahasan diadakan turnamen akademik, siswa memainkan games akademik dengan anggota tim lain untuk menyumbangkan poin bagi timnya. Tipe ini dipilih karena pada dasarnya para siswa lebih menyenangi persaingan dengan menggunakan permainan. Mereka tidak merasa jenuh, bosan dalam mengikuti pembelajaran, sambil bermain, sambil belajar. Ini merupakan salah satu kelebihan model pembelajaran kooperatif tipe Team Games Tournament (TGT).

Bedasarkan uraian di atas bentuk inovasi pembelajaran IPS yang dikembangkan dalam buku ini adalah pengembangan perangkat pembelajaran IPS model cooperative tipe TGT berbasis ATONG pada materi mendeskripsikan perjuangan para tokoh pejuang pada masa penjajahan Belanda dan Jepang. Pengembangan perangkat pembelajaran IPS tersebut merupakan pengembangan model pembelajaran TGT yang sudah ada dengan menggunakan kerangka kegiatan ATONG. Pengembangan tersebut penting dilakukan karena di dalamnya terdapat kegiatan pembelajaran yang memberikan kesempatan pada peserta didik untuk bekerjasama dalam kelompok dengan latar belakang dan kondisi yang berbeda, memberikan kesempatan kepada peserta didik untuk belajar menemukan, menggali kemampuan yang mereka miliki dengan bimbingan guru.

Kenyataan tersebut di atas memerlukan perhatian dan kreatifitas guru untuk menyusun perangkat pembelajaran yang benar dan bisa ditangkap oleh peserta didik serta menciptakan pembelajaran yang menjadikan peserta didik lebih aktif, kreatif dan efektif serta mampu meningkatkan pemahaman konsep peserta didik terhadap materi. Berdasarkan hasil wawancara dengan guru kelas $\mathrm{V}$, bahwa perangkat yang digunakan masih kurang baik maka perlu dilakukan sebuah inovasi dalam pembuatan perangkat yang dapat melibatkan aktivitas peserta 
didik dan meningkatkan hasil belajar peserta didik. Model pengembangan yang digunakan adalah model pengembangan 4-D (four D Model) yang dikemukakan oleh Thiagarajan (1974:5) yang terdiri atas empat tahap, yakni tahap pendefinisian (define), tahap perancangan (design), tahap pengembangan (develop), dan penyebaran (disseminate). Perangkat pembelajaran yang dikembangkan meliputi Silabus, Rencana Pelaksanaan Pembelajaran (RPP), Lembar Kegiatan Siswa (LKS), dan Media Pembelajaran.

Buku ini akan menjabarkan bagaimana melakukan pengembangan perangkat pembelajaran IPS model cooperatif tipe TGT berbasis ATONG untuk meningkatkan aktivitas dan prestasi belajar siswa pada materi mendeskripsikan perjuangan para tokoh pejuang pada masa penjajahan Belanda dan Jepang.

\section{B. Penegasan Istilah}

Untuk memberikan kejelasan arti dan menghindari penafsiran yang salah pada istilah yang digunakan dalam judul dan rumusan masalah, maka diberikan batasan-batasan istilah yang ada dalam buku ini.

a. Pengembangan adalah proses penyusunan perangkat pembelajaran yang memenuhi kriteria valid, praktis dan efektif. Model pengembangan perangkat yang digunakan adalah model pengembangan 4-D. Pengembangan perangkat Pembelajaran dalam buku ini menggunakan model 4-D (four D Model) yang dikemukakan oleh Thiagarajan,dkk (1974:5) yang terdiri dari empat tahap, yakni tahap pendefinisian (define), tahap perancangan (design), tahap pengembangan (develop), dan penyebaran (disseminate). Pengembangan perangkat pembelajaran hanya sampai pada uji coba lapangan sehingga sampai pada tahap pengembangan (develop). Perangkat yang dikembangkan adalah silabus, rencana pelaksaanaan pembelajaran (RPP), Lembar Kerja Siswa (LKS) dan Media Pembelajaran.

b. Pengembangan perangkat pembelajaran yang valid adalah proses untuk memperbaiki, membuat dan mengembangkan 
perangkat pembelajaran berdasarkan prosedur pengembangan perangkat pembelajaran yang telah melalui tahap validasi ahli dengan hasil bisa digunakan (Nieveen, 1999: 127).

c. Perangkat pembelajaran dikatakan praktis jika dapat diterapkan dalam pembelajaran. Untuk mengetahui hasil penggunaan perangkat pembelajaran yang praktis ditinjau dengan: (a) lembar pengamatan aktivitas guru dalam pengelolaan pembelajaran tergolong baik (b) respon peserta didik tergolong positif (Nieveen, 1999: 127).

d. Efektif dalam pengembangan di buku ini adalah (a) Prestasi belajar mencapai kriteria ketuntasan minimal, (b) ada pengaruh aktivitas belajar terhadap prestasi belajar pada pembelajaran IPS dengan model cooperative tipe TGT berbasis ATONG di Kelas V Sekolah Dasar, (c) prestasi belajar peserta didik pada pembelajaran IPS dengan model cooperative tipe TGT berbasis ATONG di Kelas V Sekolah Dasar lebih baik dibandingkan pembelajaran konvensional.

e. Ketuntasan belajar adalah pencapaian suatu tingkat penguasaan minimal dalam tujuan pembelajaran pada setiap satuan pelajaran. KKM (Kriteria Ketuntasan Minimal) yakni 70. Jika prestasi belajar lebih dari atau sama dengan KKM maka peserta didik disebut mencapai ketuntasan belajar. Ketuntasan belajar secara individual menurut Bloom (Winkel, 2007: 466) adalah apabila $80 \%$ peserta didik mencapai KKM.

f. Menurut Sardiman (2007: 100) aktivitas belajar adalah aktivitas yang bersifat fisik maupun mental. Jenis-jenis aktivitas yang dapat dilakukan oleh siswa di sekolah antara lain: visual activities, oral activities, listening activities, writing activities, drawing activities, motor activities, mental activities, emosional ectivities. Aktivitas dalam pengembangan di buku ini hanya menerapkan tujuh jenis aktivitas menurut Sardiman yaitu: visual activities, oral activities, listening activities, writing activities, motor activities, mental activities dan emosional ectivities. 
g. Menurut Arikunto (2006: 4) prestasi belajar adalah hasil dari kegiatan belajar mengajar. Prestasi belajar siswa berkenaan dengan tingkat pencapaian kompetensi dasar pada materi mendeskripsikan perjuangan para tokoh pejuang pada masa penjajahan Belanda dan Jepang. 


\section{BAB II}

KONSEP BELAJAR IPS

\section{A. Pengertian Belajar}

Belajar sebagai proses manusiawi memiliki kedudukan dan peran penting, baik dalam kehidupan masyarakat tradisional maupun modern. Untuk memahami konsep belajar secara utuh perlu digali lebih dulu bagaimana para pakar psikologi dan pakar pendidikan mengartikan konsep belajar. Pandangan kedua kelompok pakar tersebut sangat penting karena perilaku belajar merupakan bidang telaah dari kedua bidang keilmuan itu.

Slameto (2010:2), menyatakan bahwa secara psikologis belajar merupakan suatu proses perubahan yaitu perubahan tingkah laku sebagai hasil dari interaksi dengan lingkungannya dalam memenuhi kebutuhan hidupnya. Perubahan-perubahan tersebut akan nyata dalam seluruh aspek tingkah laku. Dari sisi proses, belajar ialah suatu proses usaha yang dilakukan seseorang untuk memperoleh suatu perubahan tingkah laku yang baru secara keseluruhan, sebagai hasil pengalamnnya sendiri dalam interaksi dengan lingkungnnya.

Sanjaya (2006:112), menyatakan bahwa belajar bukanlah sekedar mengumpulkan pengetahuan. Belajar adalah proses mental yang terjadi dalam diri seseorang, sehingga menyebabkan munculnya perubahan perilaku. Aktivitas mental itu terjadi karena adanya interaksi individu dengan lingkungan yang disadari. Winkel (1996:53), belajar pada manusia boleh dirumuskan sebagai suatu aktivitas mental/psikis, yang berlangsung dalam interaksi aktif dengan lingkungan, yang menghasilkan perubahan-perubahan dalam pengetahuan, pemahaman, keterampilan, nilai, dan sikap. Perubahan itu bersifat secara relatif konstan dan berbekas.

Crow (dalam Sagala, 2010: 13), belajar ialah upaya untuk memperoleh kebiasaan-kebiasaan, pengetahuan, dan sikapsikap. Sedangkan menurut Cronbach (dalam Sardiman, 2007: 
20), learning is shown by a change in behavior as a result of experience. Berbeda lagi menurut Spears (dalam Sardiman, 2007: 20), learning is to observe, to read, to imitate, to try something themselves, to listen, to follow direction. Skinner (dalam Dimyati dan Mudjiono, 2006: 9), belajar adalah suatu perilaku. Pada saat orang belajar, maka responnya menjadi lebih baik. Sebaliknya, bila ia tidak belajar maka responnya menurun.

Dapat disimpulkan bahwa belajar adalah proses yang aktif dan suatu usaha untuk memperoleh perubahan tingkah laku pada diri seseorang. Perubahan sebagai hasil proses belajar dapat ditunjukkan dalam berbagai bentuk seperti perubahan, pengetahuan, pemahaman, sikap, tingkah laku, keterampilan, kecakapan, kemampuan, daya kreasi, daya penerimaan dan segala aspek yang ada pada individu. Individu yang mengalami belajar dapat mereaksi terhadap semua situasi yang ada disekitar individu, dan suatu proses yang diarahkan kepada tujuan, proses berbuat melalui berbagai pengalaman.

\section{B. Model Cooperatif Learning (CL)}

Pandangan mengenai konsep pembelajaran terus menerus mengalami suatu perubahan dan perkembangan yang sangat pesat sesuai dengan ilmu pengetahuan dan teknologi pendidikan. Pembelajaran berlangsung dalam suatu situasi belajar mengajar yang dipengaruhi oleh banyak faktor-faktor yang saling berhubungan antara lain tujuan mengajar, guru yang mengajar, siswa yang belajar, bahan yang diajarkan, metode pembelajaran, alat bantu mengajar, situasi pembelajaran, metode mengajar, dan juga prosedur penilaian, semua faktor tersebut sangat saling berhubungan secara dinamis dalam suatu rangkaian terarah dalam rangka membawa siswa dalam mencapai tujuan pembelajaran (Sagala, 2010: 61).

Metode pembelajaran dapat dibedakan dari beberapa pendekatan. Secara sederhana pendekatan (approach) lebih menekankan pada strategi dalam perencanaan, sedangkan metode (method) lebih menekankan pada teknik pelaksanaan dalam pembelajaran. Metode merupakan suatu cara untuk 
mencapai tujuan dalam konteks pembelajaran, oleh karena itu penggunaan metode pembalajaran dirancang oleh guru memudahkan siswa dalam mencapai tujuan pembelajaran yang menyenangkan (Sholihatin dan Raharjo, 2009:5). Metode pembelajaran yang digunakan adalah pembelajaran kooperatif (Cooperative Learning) yang mana metode ini lebih banyak menekankan pada siswa untuk banyak aktif dalam proses pembelajaran untuk mencapai tujuan dari pembelajaran itu sendiri.

Pembelajaran kooperatif adalah suatu model pembelajaran yang saat ini banyak digunakan untuk mewujudkan kegiatan belajar mengajar yang berpusat pada siswa (studend oriented), terutama untuk mengatasi permasalahan yang ditemukan guru dalam mengaktifkan siswa, yang tidak dapat bekerja sama dengan orang lain, siswa yang agresif dan tidak peduli pada yang lain. Model pembelajaran ini telah terbukti dapat dipergunakan dalam berbagai mata pelajaran dan berbagai usia (Isjoni, 2009:23).

Dalam konteks pembelajaran untuk mencapai tujuan yang dinginkan oleh pendidik yaitu guru dan objek pendidik yaitu siswa pada dasarnya merupakan suatu kesinambungan proses kegiatan pembelajaran yang sebagaimana mestinya proses tersebut harus terjalin secara harmonis dan dinamis. Rasional dari suatu pembelajaran koperatif adalah bahwa siswa sebagai manusia pada hakikatnya ialah makhluk yang memiliki ketergantungan antara satu sama lainnya, memiliki tujuan bersama, dan tanggungjawab. Oleh karena itu fitrah sebagai makhluk sosial tersebut dikembangkan melaui pembelajaran kooperatif yang dapat menjalin rasa saling membantu, berinteraksi, berbagi, kompetitif dan penghargaan.

Pada pembelajaran kooperatif lebih banyak menekankan pada siswa untuk banyak belajar secara berkelompok baik kelompok kecil yang bisa dilakukan oleh dua orang atau sampai kelompok besar yang dilakukan sebanyak 6 - 8 siswa yang bekerja sama membentuk suatu kelompok kerja aktif yang keberhasilannya harus ditunjang oleh aktivitas seluruh anggota, 
sehingga anggota kelompok tersebut harus bekerja sama saling menbantu. Selain itu sebagai syarat dalam pembelajaran kooperatif adalah materi sesuai dengan pengetahuan awal siswa dan minatnya. Kelompok dibuat heterogen, ada panduan dan target, serta ditentukan waktu dan tempatnya.

Slavin (2008:10), Cooperative Learning adalah suatau model pembelajran dimana siswa belajar dan bekerja dalam kelompokkelompok kecil secara kolaboratif yang anggotanya terdiri dari 4 sampai 6 orang, dengan struktur kelompoknya yang bersifat hetrogen. Keberhasilan belajar dari kelompok tergantung pada kemampuan dan aktifitas anggota kelompok, baik secara individual maupun secara kelompok.

Dari beberapa definisi di atas, dapat dikatakan bahwa Cooperatif Learning merupakan model pembelajaran yang berbentuk kelompok terdiri dari 4 sampai 6 orang yang mengutamakan kerjasama antar kelompok dan bersifat hetrogen. Bennet dalam Isjoni (2009 : 60-61) menyatakan ada lima unsur dasar yang dapat membedakan pembelajaran kooperatif dengan kerja kelompok, yaitu :

1. Positive Interdepedence, yaitu hubungan timbal balik yang didasari adanya kepentingan yang sama atau perasaan diantara anggota kelompok dimana keberhasilan seseorang merupakan keberhasilan yang lain pula atau sebaliknya.

2. Interaction face to face, yaitu interaksi yang berlangsung terjadi antar siswa tanpa adanya perantara. Tidak adanya penonjolan kekuatan individu, yang ada hanya pola interaksi dan perubahan yang bersifat verbal diantara siswa yang ditingkatkan oleh adanya saling hubungan timbal balik yang bersifat positif sehingga dapat mempengaruhi hasil pendidikan dan pengajaran.

3. Adanya tanggung jawab pribadi mengenai materi pelajaran dalam anggota kelompok, sehingga siswa termotivasi untuk membantu temannya, karena tujuan dalam pembelajaran kooperatif adalah menjadikan setiap anggota kelompoknya menjadi lebih kuat pribadinya. 
4. Membutuhkan keluwesan, yaitu menciptakan hubungan antar pribadi, mengembangkan kemampuan kelompok, dan memelihara hubungan kerja yang efektif.

5. Meningkatkan keterampilan bekerja sama dalam memecahkan masalah (proses kelompok), yaitu tujuan terpenting yang diharapkan dapat dicapai dalam pembelajaran kooperatif adalah siswa belajar keterampilan bekerja sama dan berhubungan ini adalah keterampilan yang penting dan sangat diperlukan di masyarakat.

Tiga konsep sentral yang menjadi karakteristik pembelajaran kooperatif sebagaimana dikemukakan Slavin (2008: 26-27), yaitu :

1. Tujuan Kelompok

Pembelajaran kooperatif menggunakan tujuan-tujuan kelompok untuk memperoleh penghargaan kelompok. Penghargaan kelompok diperoleh jika kelompok mencapai skor di atas kriteria yang ditentukan. Keberhasilan kelompok didasarkan pada penampilan individu sebagai anggota kelompok dalam menciptakan hubungan antar person yang saling mendukung, saling membantu, dan saling peduli.

2. Tanggung Jawab Individual

Keberhasilan kelompok tergantung dari pembelajaran individu dari semua anggota kelompok. Pertanggung jawaban tersebut menitik beratkan pada aktivitas anggota kelompok yang saling membantu dalam belajar. Adanya pertanggungjawaban secara individual juga menjadikan setiap anggota siap untuk menghadapi tes dan tugas-tugas lainnya secera mandiri tanpa bantuan teman sekelompoknya.

3. Kesempatan Sukses yang Sama

Pembelajaran kooperatif mengguakan metode skoring yang mencakup nilai perkembangan berdasarkan peningkatan prestasi yang diperoleh siswa dari yang terdahulu. Dengan menggunakan metode skoring ini setiap siswa baik yang berprestasi rendah, sedang, atau tinggi sama- 
sama memperoleh kesempatan untuk berhasil dan melakukan yang terbaik buat kelompoknya.

Stahl dalam Sholihatin dan Raharjo (2008:7-9), di dalam menggunakan Cooperative Learning di dalam kelas, harus diperhatikan dan diupayakan beberapa konsep yang mendasar yaitu :

1. Perumusan tujuan belajar siswa yang harus jelas.

2. Permainan yang menyeluruh oleh siswa tentang tujuan belajar.

3. Ketergantungan yang bersifat positif.

4. Interaksi yang bersifat terbuka.

5. Tanggung jawab individual.

6. Kelompok bersifat heterogen.

7. Interaksi sikap dan perilaku sosial yang positif.

8. Tindak lanjut (Follow Up).

9. Kepuasan dalam belajar.

Langkah-langkah dalam penggunaan model Cooperative Learning secara umum dapat dijelaskan (Sholihatin dan Raharjo, 2008:10-11) sebagai berikut :

1. Langkah pertama adalah merancang rencana program pembelajaran. Pada langkah ini guru harus mempertimbangkan dan menetapkan target pembelajaran yang ingin dicapai dalam pembelajaran.

2. Langkah kedua, dalam aplikasi pembelajaran di kelas, guru harus merancang lembar observasi yang akan digunakan untuk mengobservasi kegiatan siswa dalam belajar secara bersama dalam kelompok-kelompok kecil.

3. Langkah ketiga, dalam melakukan observasi terhadap kegiatan siswa, guru harus mengarahkan dan membimbing siswa, baik secara individual maupun kelompok, baik dalam memahami materi maupun mengenai sikap dan perilaku siswa selama kegiatan belajar berlangsung. 
4. Langkah keempat, guru memberikan kesempatan kepada siswa dari masing-masing kelompok untuk mempersentasikan hasil kerjanya.

\section{Tipe Team Games Tournament (TGT)}

Team Games Tournament (TGT) merupakan metode pembelajaran yang melibatkan kerjasama tim untuk melakukan games akademik yang dilakukan pada akhir unit pokok bahasan. Slavin (2008:166-185), didalam pembelajaran kooperatif tipe Team Games Tournament (TGT) ada beberapa komponen utama yaitu :

1. Presentasi Kelas.

Materi dalam model pembelajaran kooperatif tipe TGT (Team Games Tournament) pertama-pertama siswa diperkenalkan dalam presentasi di dalam kelas. Ini merupakan pengajaran langsung seperti yang sering kali dilakukan atau diskusikan pelajaran yang dipimpin oleh guru, tetapi bisa juga memasukan presentasi audiovisual. Dalam pembelajaran guru hanya memfokuskan materi yang diajarkan saja. Dengan cara ini, para siswa akan menyadari bahwa mereka harus benar-benar memberi perhatian penuh selama presentasi kelas, karena dengan demikian akan sangat membantu mereka mengerjakan game akademik dengan sebaik-baiknya, dan sekor yang didapat dalam turnamen akan menentukan sekor kelompok mereka.

2. Tim

Tim terdiri dari empat atau lima siswa yang mewakili seluruh bagian dari kelas dalam hal kinerja akademik, jenis kelamin, ras dan etnis. Fungsi utama dari tim ini adalah memastikan bahwa semua anggota tim benar-benar belajar, dan lebih khususnya lagi, adalah untuk mempersiapkan anggotanya untuk bisa mengerjakan game dengan baik. Tim adalah fitur yang paling penting dalam TGT. Pada tiap poinnya, yang ditekankan adalah membuat anggota tim melakukan yang terbaik untuk tim, dan tim pun harus melakukan yang terbaik untuk membantu tiap anggotanya. 


\section{Game}

Game terdiri dari atas pertanyaan-pertanyaan yang kontennya relevan yang dirancang untuk menguji pengetahuan siswa yang diperolehnya dari persentasi di kelas dan pelaksanaan kerja tim. Game tersebut dimainkan di atas meja dengan tiga atau empat orang siswa, yang masingmasing mewakili tim yang berbeda. Kebanyakan game hanya berupa nomor-nomor pertanyaan yang ditulis pada lembar yang sama. Seorang siswa mengambil sebuah kartu bernomor dan harus menjawab pertanyaan sesuai dengan nomor yang tertera pada kartu tersebut. Sebuah aturan tentang penantang memperbolehkan para pemain saling menantang jawaban masing-masing.

4. Turnamen

Turnamen adalah sebuah struktur di mana game berlangsung. Biasanya dilaksanakan pada akhir minggu atau akhir unit pokok bahasan, setelah guru memberikan penyajian kelas atau kelompok mengerjakan lembar kerjanya. Untuk Ilustrasi turnamen dapat dilihat pada Gambar 2.1.

TIM A

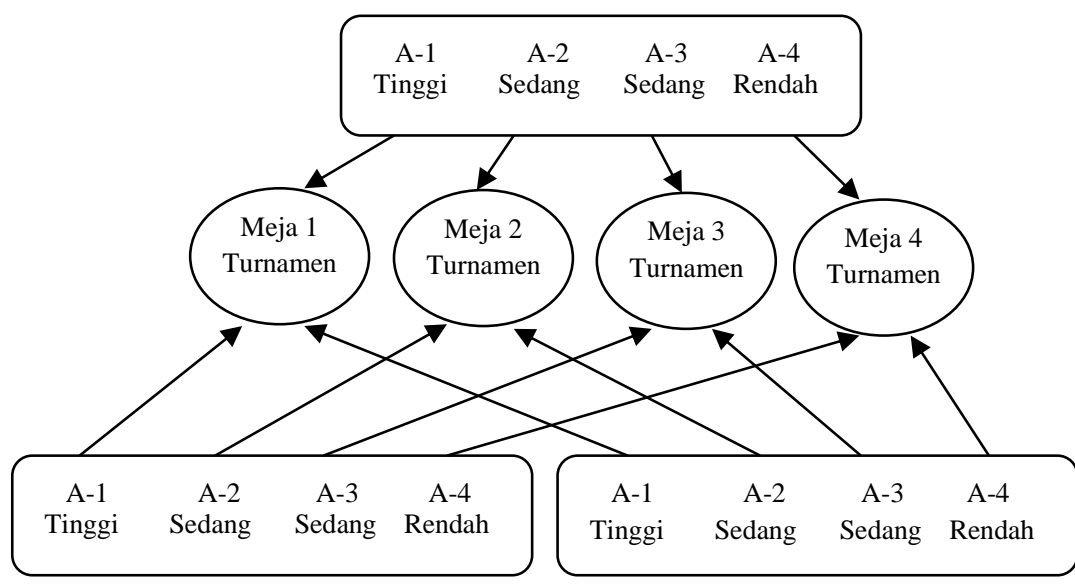

TIM B

TIM C

Gambar 2.1: Skema penempatan siswa kedalam meja turnamen menurut Slavin (2009:168). 
Setelah turnamen pertama, para siswa akan bertukar meja tergantung pada kinerja mereka pada turnemen terakhir. Pemenang pada tiap meja "naik tingkat" ke meja berikutnya yang lebih tinggi (misalnya, dari meja 6 ke meja 5) skor tertinggi kedua tetap tinggal pada meja yang sama; dan yang skornya paling rendah "diturunkan." Dengan cara ini, jika pada awalnya siswa sudah salah ditempatkan, untuk seterusnya mereka akan terus dinaikan atau diturunkan sampai mereka mencapai tingkat kinerja mereka yang sesungguhnya.

5. Rekognisi Tim

Pengukuhan kelompok dilakuakan dengan memberikan penghargaan berupa hadiah atau sertifikat atas usaha yang telah dilakukan kelompok selama belajar sehingga mencapai kriteria yang telah disepakati bersama. Ada 3 tingkatan penghargaan yang berdasarkan pada skor rata-rata tim yaitu :

Tabel 2.1 : Penghargaan berdasarkan skor rata-rata tim (Slavin: 2009:175)

\begin{tabular}{|c|l|}
\hline $\begin{array}{c}\text { Kriteria (Rata-Rata } \\
\text { Tim) }\end{array}$ & \multicolumn{1}{|c|}{ Penghargaan } \\
\hline 40 & Tim Baik (Good Team ) \\
45 & Tim Sangat Baik (Great Team) \\
50 & Tim Super (Super Team) \\
\hline
\end{tabular}

Slavin (2009:169) sebelum memulai TGT (Team Games Tournament) ada beberapa persiapan yang harus diperhatikan antara lain :

1. Materi yang akan diajarkan.

Materi yang terkait dengan materi yang akan diajarkan oleh guru, materi itu bisa bersumber dari buku paket/cetak atau dari materi yang dibuat oleh guru untuk menunjang proses pembelajaran di dalam kelas. 
2. Menempatkan siswa dalam tim.

Setiap tim dalam pembelajaran kooperatif tipe TGT sebanyak 4 - 6 siswa, yang terdiri dari siswa pandai, sedang, dan kurang. Selain itu dalam pembagian kelompok guru sebaiknya mempertimbangkan kriteria lainnya misalnya jenis kelamin, latar belakang social, dan kinerja.

3. Menempatkan siswa kedalam meja turnamen.

Dalam satu meja turnamen terdiri dari 3 sampai 4 siswa yang ber kompetensi dengan kemampuan setara dan sebagai wakil tim yang berbeda. Misalkan siswa rangking pertama pada setiap tim pada meja I, empat rangking berikutnya pada meja II, empat rangking berikutnya pada meja III dan seterusnya.

\section{Strategi Pembelajaran ATONG}

Proses pembelajaran yang dilakukan oleh guru tidak bisa terlepas dari penerapan strategi pembelajaran. Strategi pembelajaran digunakan oleh guru sebagai pedoman dan acuan bertindak yang sistematis dalam pelaksanaan pembelajaran. Bagi siswa penggunaan strategi pembelajaran dapat mempermudah proses pembelajaran dan mempercepat memahami isi pembelajaran. Diharapkan dengan Guru menggunakan strategi pembelajaran maka hasil belajar siswa akan meningkat. Salah satu strategi pembelajaran yang dapat diterapkan dalam proses pembelajaran yaitu strategi pembelajaran ATONG. Muslim (2016:04) menjelaskan bahwa:

Strategi pembelajaran ATONG adalah pembelajaran yang dipolakan pada suasana A (amati) terhadap semua situasi belajar, lalu $\mathrm{T}$ (tanya) pada setiap masalah yang muncul, supaya mereka melakukan $\mathrm{O}$ (olah) atas jawaban dari pertanyaan, kemudian $\mathrm{N}$ (nalar) untuk seterusnya sampai pada $\mathrm{G}$ (gagas) suatu ide atau inovasi baru.

Proses pembelajaran ATONG melibatkan aktivitas siswa secara aktif. Menurut Muslim (2016:04) menjelaskan Pembelajaran ATONG melibatkan keterampilam proses seperti 
mengamati, mengklarifikasi, mengukur, mengamalkan, menjelaskan, dan menyimpulkan. Dalam melaksanakan prosesproses tersebut, bantuan pendidik diperlukan. Strategi pembelajaran ATONG merupakan pengembangan dari pendekatan saintifik, sehingga tahapan pada strategi pembelajaran ATONG mengambil langkah dari pendekatan saintifik yang sesuai untuk pembelajaran tematik. langkahlangkah strategi pembelajaran ATONG yaitu :

1. Amati

Metode mengamati mengutamakan kebermaknaan proses pembelajaran (meaningfull learning). Metode ini memiliki keunggulan tertentu, seperti menyajikan media objek secara nyata, peserta didik senang dan tertantang, dan mudah pelaksanaanya. Guru memfasilitasi peserta didik untuk melakukan pengamatan, melatih mereka untuk memperhatikan (melihat, membaca, mendengar) hal yang penting dari suatu benda atau objek.

2. Tanya

Guru membuka kesempatan secara luas kepada peserta didik untuk bertanya mengenai apa yang sudah dilihat, disimak, dibaca. Guru perlu membimbing peserta didik untuk dapat mengajukan pertanyaan. Pertanyaan tentang hasil pengamatan objek yang konkret sampai kepada yang abstrak berkenaan dengan fakta, konsep, prosedur, ataupun hal lain yang lebih abstrak. Fungsi dari bertanya adalah mendorong dan menginspirasi peserta didik untuk aktif belajar, serta mengembangkan pertanyaan dari dan untuk dirinya sendiri.

3. Olah

Mengolah dalam kegiatan pembelajaran yaitu mengolah informasi. Mengolah informasi berarti informasi yang diterima tidak hanya didengarkan, namun juga ditulis. Hasil dari pengolahan informasi akan digunakan pada tahap selanjutnya. 


\section{Nalar}

Kegiatan menalar yaitu proses berfikir yang logis dan sistematis atas fakta-fakta empiris yang dapat diobservasi untuk memperoleh simpulan beberapa pengetahuan. Istilah asosiasi dalam pembelajaran merujuk pada kemauan mengelompokan beragam ide dan mengasosiasikan beragam peristiwa untuk kemudian memasukannya menjadi penggalan memori. Penalaran adalah proses berfikir yang logis dan sistematis atas fakta kata empiris yang dapat diobservasi untuk memperoleh simpulan berupa pengetahuan.

5. Gagas (mengkomunikasikan)

Guru diharapkan memberi kesempatan kepada peserta didik untuk mengkomunikasikan apa yang telah mereka pelajari. Kegiatan ini dapat dilakukan melalui menuliskan atau menceritakan sesuatu yang ditemukan dalam kegiatan mencari informasi, mengasosiasikan dan menemukan pola.

\section{E. Model Cooperatif tipe TGT berbasis ATONG}

Langkah-langkah dalam pembelajaran TGT (Team Games Tournament) berbasis ATONG. Berbasis ATONG dimaksudkan sesuai pesan kurikulum 2013, bahwa pembelajaran dilaksanakan menggunakan pendekatan ilmiah. Proses pembelajaran menyentuh tiga ranah, yaitu sikap, pengetahuan, dan keterampilan. Dalam proses pembelajaran berbasis pendekatan ilmiah, ranah sikap menggamit transformasi substansi atau materi ajar agar peserta didik "tahu mengapa." Ranah keterampilan menggamit transformasi substansi atau materi ajar agar peserta didik "tahu bagaimana". Ranah pengetahuan menggamit transformasi substansi atau materi ajar agar peserta didik "tahu apa." Hasil akhirnya adalah peningkatan dan keseimbangan antara kemampuan untuk menjadi manusia yang baik(soft skills) dan manusia yang memiliki kecakapan dan pengetahuan untuk hidup secara layak (hard skills) dari peserta didik yang meliputi aspek kompetensi sikap, keterampilan, dan 
pengetahuan. Pendekatan ilmiah (pendekatan scientific) dalam pembelajaran sebagaimana dimaksud meliputi mengamati, menanya, mencoba, mengolah, menyajikan, menyimpulkan, dan mencipta untuk semua mata pelajaran. Pendekatan ilmiah pembelajaran disajikan berikut ini.

1. Mengamati

Metode mengamati mengutamakan kebermaknaan proses pembelajaran (meaningfull learning). Metode ini memiliki keunggulan tertentu, seperti menyajikan media obyek secara nyata, peserta didik senang dan tertantang, dan mudah pelaksanaannya. Metode mengamati sangat bermanfaat bagi pemenuhan rasa ingin tahu peserta didik. Sehingga proses pembelajaran memiliki kebermaknaan yang tinggi. Dengan metode observasi peserta didik menemukan fakta bahwa ada hubungan antara obyek yang dianalisis dengan materi pembelajaran yang digunakan oleh guru.

2. Menanya

Guru yang efektif mampu menginspirasi peserta didik untuk meningkatkan dan mengembangkan ranah sikap, keterampilan, dan pengetahuannya. Pada saat guru bertanya, pada saat itu pula dia membimbing atau memandu peserta didiknya belajar dengan baik. Ketika guru menjawab pertanyaan peserta didiknya, ketika itu pula dia mendorong asuhannya itu untuk menjadi penyimak dan pembelajar yang baik.

3. Menalar

Selama proses pembelajaran, guru dan peserta didik sering kali menemukan fenomena yang bersifat analog atau memiliki persamaan. Dengan demikian, guru dan peserta didik adakalanya menalar secara analogis. Analogi adalah suatu proses penalaran dalam pembelajaran dengan cara membandingkan sifat esensial yang mempunyai kesamaan atau persamaan.

4. Mencoba

Untuk memperoleh hasil belajar yang nyata atau otentik, peserta didik harus mencoba atau melakukan 
percobaan, terutama untuk materi atau substansi yang sesuai. Peserta didik pun harus memiliki keterampilan proses untuk mengembangkan pengetahuan tentang alam sekitar, serta mampu menggunakan metode ilmiah dan bersikap ilmiah untuk memecahkan masalah-masalah yang dihadapinya sehari-hari.

Sejalan dengan penelitian, Supartono proses pembelajarannya kelak diterapkan bersama mata pelajaran yang bersangkutan dengan berbasis pada ATONG. Berbasis ATONG dimaksudkan sesuai pesan kurikulum 2013, disamping pembelajaran dipolakan dengan eksplorasi, elaborasi dan konfirmasi, juga ditambah siswa selalu dibawa pada suasana $\mathrm{A}$ (=amati) terhadap semua situasi belajar, lalu $\mathrm{T}(=$ tanya) pada setiap masalah muncul, supaya mereka melakukan $\mathrm{O}(=$ olah $)$ atas jawaban dari pertanyaan, kemudian $\mathrm{N}(=$ nalar) untuk diteruskan sampai pada $\mathrm{G}(=$ gagas) suatu ide atau inovasi baru.

Langkah-langkah pembelajarannya yaitu: Pelajaran di awali dengan memberikan pelajaran oleh guru, selanjutnya diumumkan kepada semua siswa bahwa akan melaksanakan pembelajaran kooperatif tipe TGT (Team Games Tournament) dan siswa diminta memindahkan bangku untuk mebentuk meja tim. Kepada siswa disampaikan bahwa mereka akan bekerja sama dengan kelompok belajar selama beberapa pertemuan, kemudian mengikuti permainan (game akademik) untuk memperoleh poin bagi nilai tim mereka serta diberitahukan tim yang memperoleh nilai tinggi akan mendapatkan rekognisi (penghargaan).

Kegiatan dalam turnamen adalah persaingan pada meja turnamen dari 3-4 siswa dari tim yang berbeda dengan kemampuan setara. Pada permulaan turnamen diumumkan penetapan meja turnamen bagi siswa. Siswa diminta mengatur meja turnamen yang ditetapkan. Nomor meja turnamen dapat diacak. Setelah kelengkapan dibagikan dapat dimulai kegiatan permainan.

Pada akhir putaran pemenang mendapat satu kartu bernomor, penantang yang kalah mengembalikan prolehan 